\title{
Habitat complexity does not influence prey consumption in an experimental three-level trophic chain
}

\author{
Rafaela V. Granzotti (D), Carolina M. Muniz (D) \& Luiz C. Gomes (1)
}

Universidade Estadual de Maringá, Programa de Pós-Graduação em Ecologia de Ambientes Aquáticos Continentais. Avenida Colombo, 5790, Maringá, PR, 87020-900, Brasil. (rafaelagranzotti@gmail.com)

\author{
Received 6 July 2017 \\ Accepted 24 June 2018 \\ Published 16 July 2018 \\ DOI 10.1590/1678-4766e2018028
}

\begin{abstract}
Habitat complexity influences species diversity and regulates trophic interactions, mostly by increasing resource partitioning within habitats and providing refuge for prey. The influence of habitat complexity on more than two trophic levels is not well understood, mainly because behavioral modifications of prey and predator may influence the outcome of trophic interactions. Thus, we conducted a two-factor experiment with a three-level trophic chain: a piscivorous fish [Hoplerythrinus unitaeniatus (Spix \& Agassiz 1829)], an invertivorous fish (Moenkhausia forestii Benine, Mariguela \& C. de Oliveira, 2009) and an aquatic macroinvertebrate (Chironomidae larvae). We measured prey consumption in low, intermediate and high habitat complexity, provided by submerged macrophyte densities, in the presence and the absence of the piscivore, intending to test the hypothesis that higher habitat complexities decrease predators foraging success in different trophic levels. We calculated the percentage of consumed prey in all treatment combinations. There was no significant effect of habitat complexity on prey consumption for neither the piscivorous nor the invertivorous fish, but a positive correlation was found between the percentages of consumed prey by both the piscivore and the invertivore. Observed modifications in the foraging behavior of the piscivore may have resulted in similar prey consumptions in low and high macrophyte densities. Moreover, more active $M$. forestii could have suffered a higher predation pressure by H. unitaeniatus, resulting in the positive correlation found. We conclude that behavior patterns in different habitat complexities possibly influenced predation rates in the three experimental trophic levels.
\end{abstract}

KEYWORDS. Macrophytes, predator-prey interactions, piscivory, foraging behavior.

RESUMO. A complexidade de habitat influencia a diversidade de espécies e regula interações tróficas, principalmente por possibilitar a partição de recurso nos habitats e fornecer refúgio para presas. A influência da complexidade de habitat sob mais de dois níveis tróficos não é bem compreendida, especialmente porque modificações comportamentais das presas e dos predadores podem influenciar o resultado das interações tróficas. Assim, nós conduzimos um experimento bifatorial com uma cadeia trófica de três níveis: um peixe piscívoro [Hoplerythrinus unitaeniatus (Spix \& Agassiz 1829)], um peixe invertívoro (Moenkhausia forestii Benine, Mariguela \& C. de Oliveira, 2009) e um macroinvertebrados aquático (larvas de Chironomidae). Mensuramos o consumo de presas em complexidades de habitat baixa, intermediária e alta, dada por diferentes densidades de macrófitas submersas, na presença e ausência do piscívoro, com o intuito de testar a hipótese de que complexidades de habitat mais altas diminuem o sucesso de forrageio de predadores em diferentes níveis tróficos. Calculamos a porcentagem de presas consumidas em todas as combinações de tratamentos. Não houve efeito significativo da complexidade de habitat no consumo de presas para o peixe piscívoro nem para o peixe invertívoro, mas uma correlação positiva foi encontrada entre as porcentagens de presas consumidas pelo piscívoro e pelo invertívoro. Modificações observadas no comportamento de forrageio do piscívoro podem ter resultado em consumo de presas similar em densidades baixas e altas de macrófitas. Além disso, indivíduos de $M$. forestii com maior taxa de forrageamento podem ter sofrido maior pressão de predação por $H$. unitaeniatus, resultando na correlação positiva encontrada. Concluímos que padrões comportamentais em diferentes complexidades de habitat possivelmente influenciaram as taxas de predação nos três níveis tróficos experimentais.

PALAVRAS-CHAVE. Macrófitas, interações predador-presa, piscivoria, comportamento de forrageio.

Structural complexity and habitat heterogeneity have known effects on species distributions and their interactions (KovalenKo et al., 2012). The terms "complexity" and "heterogeneity" are often used interchangeably in the literature, even though they refer to different aspects of the habitat (TOKESHI \& ARAKAKI, 2012). Habitat complexity refers to the fractal structure of the habitat, that is, the abundance of individual elements that generate physical structure in the environment. On the other hand, habitat heterogeneity refers to the presence and abundance of different structure-generating pieces in said habitat (MCCoY \& BeLL, 1991; BeCK 2000).
The effects of habitat complexity and heterogeneity on species diversity are, in general, positive, in both aquatic (TANiguchi et al., 2003; GraTWICKE \& SPEIGHT, 2005; WARFE \& BARMUta, 2006; Thomaz et al., 2008) and terrestrial environments (MACARTHUR \& MACARTHUR, 1961; AUGUST, 1983). Among other factors, the greater diversity in structured environments has been attributed to the higher availability of refuge in complex habitats, which can influence predator-prey interactions (CROWDER \& COOPER, 1982; HIXON \& MENGE, 1991; Beukers \& JoNes, 1997; WARFE \& BARMUtA, 2006). Most studies in this field have found a decrease in predators 
foraging efficiency and an increase in prey survivorship in habitats with greater complexity (e.g. Heck \& Thoman, 1981; Savino \& Stein, 1982; Diehl, 1988; Gotceitas \& Colgan, 1989; Mattila, 1992; Piko \& Szedlmayer, 2007). Possible explanations for these results included a reduction in predator visual efficiency and mobility (HECK \& THOMAN, 1981; Savino \& Stein, 1982; Diehl, 1988; Manatunge et al., 2000; ALEXANDER et al., 2015) and the presence of refuge that provides partial or total protection for prey against predation (PERsSON \& EkLOv, 1995; AJEMIAN et al., 2015; HUANG et al., 2016).

The effect of habitat structure on predator-prey interactions may depend on predation tactics exhibited by predators (Heck \& Crowder, 1991; JAMES \& HeCK JR., 1994; AgostinHo et al., 2003) and antipredatory behavior of prey (Crowder \& COOPER, 1982; HeCK \& Crowder, 1991). Thus, behavior-linked factors such as these can mask the influence of habitat complexity on predation success, especially when predators shift their foraging mode, thereby increasing their predation success (SAVINO \& STEIN, 1989; EINFALT et al., 2012; Hovel et al., 2016).

In freshwater environments, macrophyte banks provide the main structured habitats for macroinvertebrate and fish (Agostinho et al., 2003; Thomaz et al., 2008; Thomaz \& CunHa, 2010; KovalenKo et al., 2012; TOKESHI $\&$ ARAKAKI, 2012). In such environments, there have been performed many experimental tests on the influence of habitat structure on predation success (e.g. DieHL, 1988; PADIAL et al., 2009; FigUeIREDo et al., 2013) and on behavioral and habitat use modifications of invertivorous fish in the presence of a predator (e.g. SAVINO \& STEIN 1989; PERSSON \& EKLOV 1995; FigUeIREDO et al., 2016). However, few experimental studies consider the influence of habitat complexity on more than two trophic levels, especially in freshwaters. This is important because some non-lethal effects of predation (i.e. modifications in prey behavior and habitat use, in the presence of predators; LIMA, 1998) can result in changes in the intensity of trophic interactions. These modifications will affect lower trophic levels' attributes such as survivorship, abundance and community structure (e.g. TURNER, 1997; GrabowsKi, 2004; GrabowsKI \& Kimbro, 2005; Warfe \& BARMUTA, 2006).

Thereby, the main purpose of this study was to determine, using an experimental approach, the effect of different levels of habitat complexity on prey consumption using a three-level trophic chain, typical of freshwater systems: a piscivorous fish, an invertivorous fish and an aquatic macroinvertebrate. We also aimed to investigate the influence of habitat complexity separately on invertivoremacroinvertebrate and piscivore-invertivore interactions. Considering that submerged macrophytes offer refuge for both invertivorous fish and macroinvertebrates, such as insect larvae (e.g. Agostinho et al., 2003; PAdial et al., 2009; THOMAZ \& CUNHA, 2010), prey consumption by both the piscivorous and the invertivorous fish were determined in low, intermediate and high density of submerged macrophytes for both predator-prey interactions. This allowed us to test the hypothesis that greater habitat complexities decrease predators foraging success, and to test this effect in different trophic levels.

\section{MATERIAL AND METHODS}

Sampling and handling of individuals. We selected the following species to compose the experiment: Hoplerythrinus unitaeniatus (Spix \& Agassiz 1829) (Characiformes, Erythrinidae), the piscivorous predator, Moenkhausia forestii Benine, Mariguela \& Oliveira, 2009 (Characiformes, Characidae), the invertivorous predator, and Chironomidae larvae (Diptera), the basal prey. Chironomidae larva are among the most abundant macrophyte-associated invertebrates in freshwater ecosystems (e.g. TAKEDA et al., 2003; Mormul et al., 2006; Thomaz et al., 2008) and are found in the diet of small fish (CASATti, 2003; Tófoli et al., 2010). Moenkhausia species, including $M$. forestii, are invertivorous characids that feed predominantly on insect larva and microcrustaceans (HAHN et al., 2004; Tófoli et al., 2010) and the genus is abundant in freshwater systems along South America (AgostinHo et al., 2003). Hoplerythrinus unitaeniatus is considered a voracious piscivore (BRITSKI et al., 1999), naturally occurring in macrophyte abundant environments (Gomes et al., 2012) in several neotropical river basins, and there are no records of this species feeding on insect larva (HAHN et al., 2004). Fishes in the Erythrinidae family can present a sit-and-wait predatory behavior (AlmEIDA et al., 1997; LuZ-AgOsTiNHO et al., 2008), but there is little research on H. unitaeniatus behavior (B. R. Belini, unpubl. data).

Individuals of the fish species were collected in the upper Paraná river floodplain, in the Baia river $\left(53^{\circ} 17^{\prime} 6^{\prime \prime} \mathrm{W}\right.$, $22^{\circ} 44^{\prime} 6^{\prime \prime}$ 'S for $H$. unitaeniatus, and 53 $17^{\circ} 28^{\prime \prime} \mathrm{W}, 22^{\circ} 43^{\prime} 07^{\prime \prime} \mathrm{S}$ for M. forestii). Hoplerythrinus unitaeniatus individuals were captured using fishing rods baited with fish and Moenkhausia forestii individuals were captured with a seining net. Fish were taken to the laboratory at Universidade Estadual de Maringá (Paraná, Brazil) and acclimated in $1000 \mathrm{~L}$ tanks for 60 days. During this period, H. unitaeniatus were fed with live bait fish to satiation and M. forestii were fed with dry commercial food. Submerged aquatic macrophytes were collected in macrophyte banks in the Paraná river. Chironomidae larva of the genus Chironomus were collected in an urban stream and kept in sand filled trays. This genus presents a characteristic reddish color and has been used in several experiments as prey for small characids (PADIAL $e t$ al., 2009; FigUeIREDo et al., 2015a).

Experimental design. To assess the effect of habitat complexity on prey consumption in different trophic levels, we designed a two-factor experiment: Factor 1: habitat complexity with three levels (low, intermediate and high); and Factor 2: Piscivorous predator with two levels (presence and absence of Hoplerythrinus unitaeniatus), totaling 6 treatment combinations (Fig. 1). In the presence of the piscivore, each habitat complexity level was replicated 5 times to obtain a better estimate of the experimental error due to variability in 
the behavior of this piscivorous species (B. R. Belini, unpubl. data). In the absence of it, each habitat complexity level was replicated 3 times, thus totalizing 24 experimental units.

Habitat complexity was represented in this study as different densities of macrophytes, and macrophyte biomass was controlled for each complexity level (low: $70 \mathrm{~g}$, intermediate: $130 \mathrm{~g}$, and high: $250 \mathrm{~g}$, respectively). Macrophyte banks used in the experiment were composed by two submerged macrophyte species: Egeria sp. and Hydrilla verticillata (L. F.) Royle. Both species present similar architectures and do not differ in fish refuging (FIGUEIREDO et al., 2015b) or foraging activities (CuNHA et al., 2011; CARniatto et al., 2014). Macrophyte densities were based on natural occurring densities found by SousA et al. (2010), adapted to the experiment scale. To numerically measure complexity, the percentage of volume infested (PVI) for each aquarium was calculated (CANFIELD et al., 1984), following BuRKs et al. (2001) (macrophyte cover area multiplied by plant height and divided by aquarium water level). Mean
PVI for each low, intermediate and high complexities were $16.1 \pm 0.8 ; 29.6 \pm 2.8$ and $60.8 \pm 2.8$, in percentages. Before added to aquaria, macrophytes were washed in running cold water to detach any undesired organisms.

A pilot experiment was conducted in which consuming rates and acclimation period time were assessed. In the pilot, Moenkhausia forestii were acclimated to experimental conditions and not fed for $24 \mathrm{~h}$; they consumed Chironomidae larvae in all treatments. The piscivore was acclimated and starved for 14 days but did not consume any prey in any macrophyte density level. Thus, we concluded that the acclimation period for the invertivore was adequate, but we increased acclimation time for the piscivore to 21 days.

The experiment was conducted in an isolated room (closed doors) and with controlled luminosity, in $40 \mathrm{~L}$ aquaria, all covered on the sides by dark paper to minimize external influences, and with mean temperature of $26.5 \pm$ $0.88^{\circ} \mathrm{C}$. Water from the same water supply system was used in all aquaria, after 3 days of pre-storage in tanks with
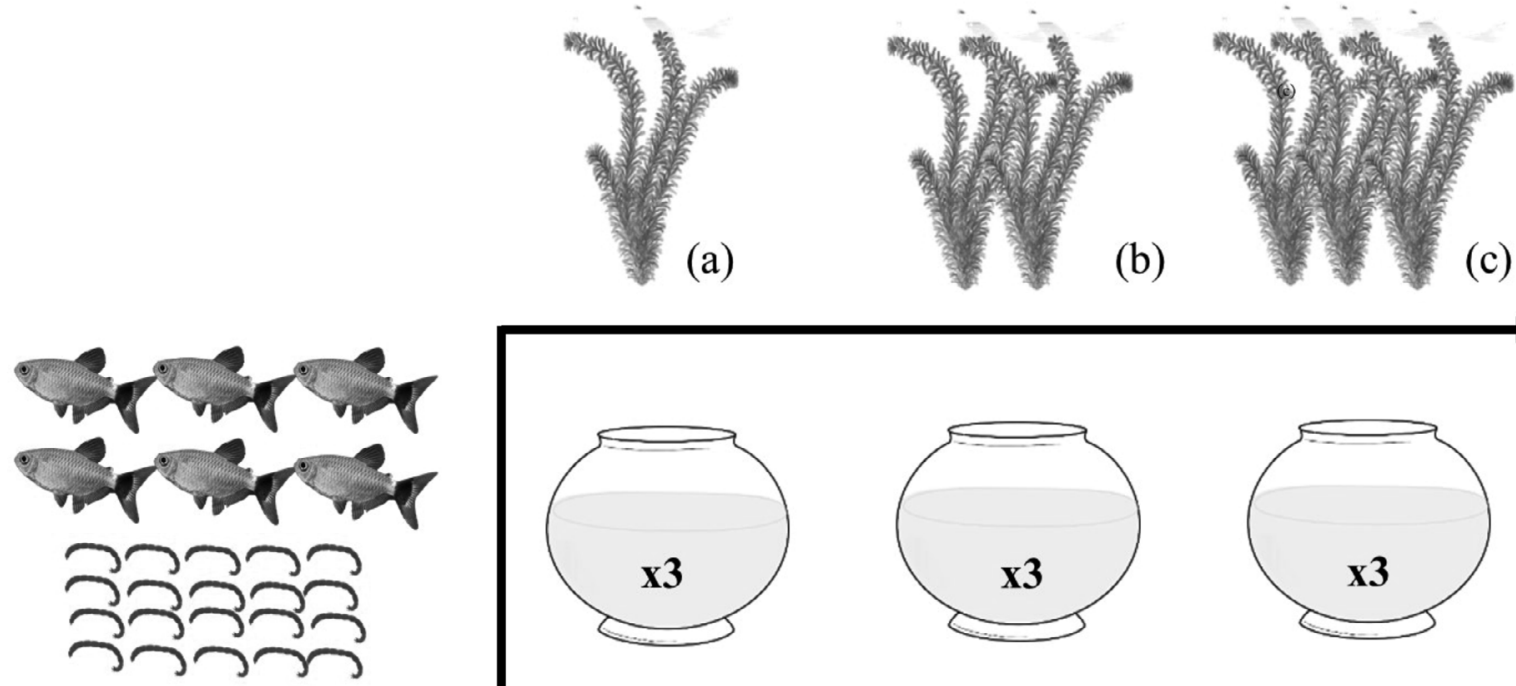

(d)
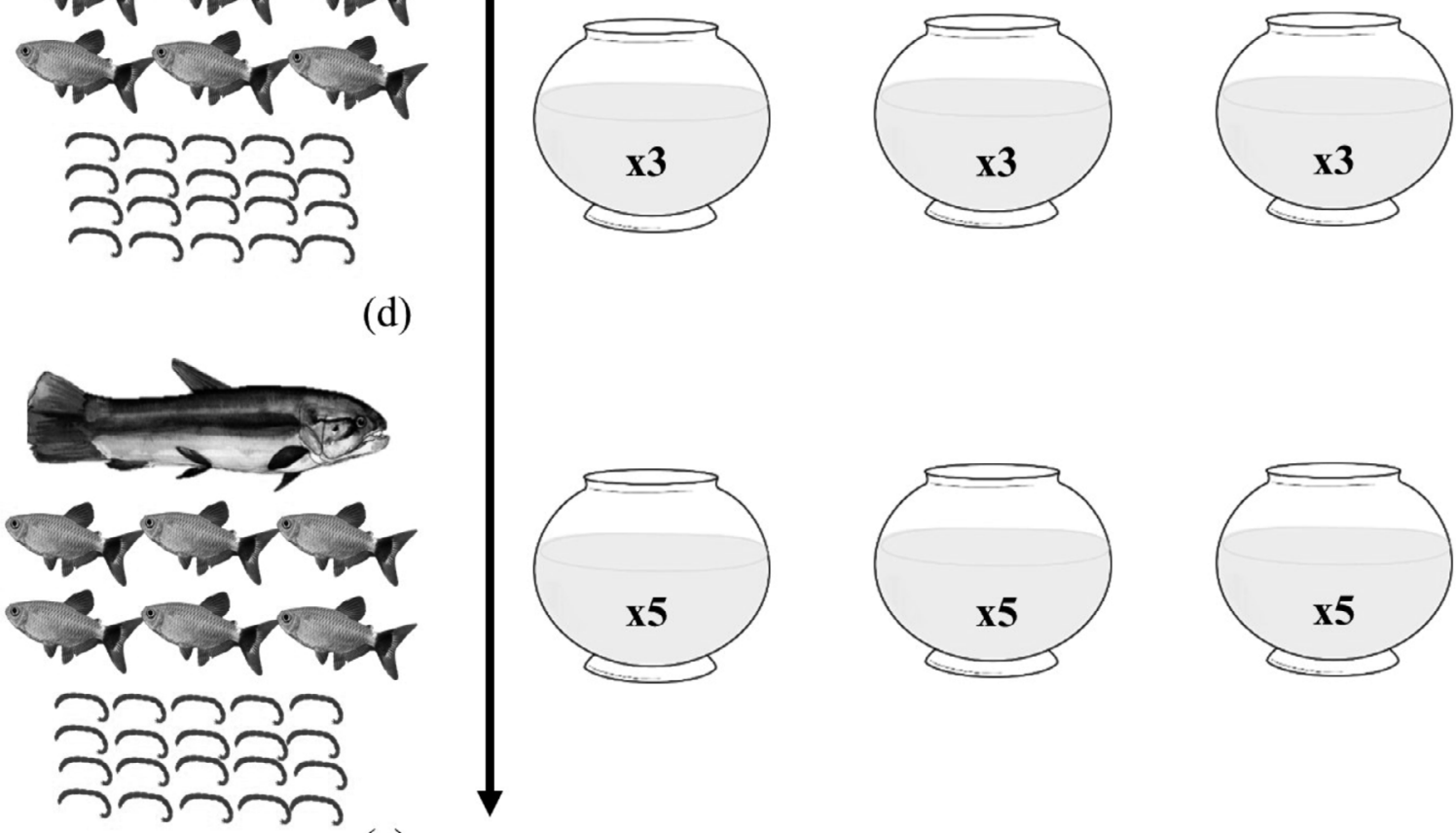

(e)

(B)
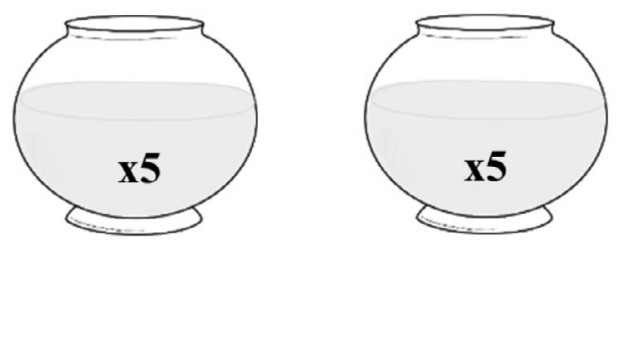

Fig. 1. The experimental design. The (A) axis represents habitat complexity [(a) low, (b) intermediate and (c) high] and the (B) axis represents the piscivore [(d) absence and (e) presence]. Numbers in the aquaria represent the number of replicates for each treatment combination. 
no fish. To maintain aquatic macrophytes always at the same position, a wide wired mesh $(5 \mathrm{~cm}$ width) was placed inside each aquarium, enabling both fish species to move freely in the aquarium. In each experimental unit assigned to presence of the piscivorous predator, we added one individual of Hoplerythrinus unitaeniatus, six individuals of Moenkhausia forestii and 20 larvae of Chironomidae. We used six individuals of the intermediate predator to reduce the effects of possible individual differences in feeding and for its shoal behavior (e.g. Padial et al., 2009; Figueiredo et al., 2013). Fish individuals were weighted before being added to aquaria: $H$. unitaeniatus ranged from $49.3 \mathrm{~g}$ to $76.9 \mathrm{~g}$, M. forestii individuals ranged from $0.32 \mathrm{~g}$ to $1.67 \mathrm{~g}$, and total M. forestii biomass ranged from $3.7 \mathrm{~g}$ to $5.9 \mathrm{~g}$. There was no difference in fish weights across treatments (One-Way ANOVA for $H$. unitaeniatus weights, $\mathrm{p}=0.69$; Two-Way ANOVA for $M$. forestii total biomass, $\mathrm{p}>0.34$ for both factors and interaction).

Hoplerythrinus unitaeniatus individuals were placed in the aquaria to acclimate to experimental conditions for 21 days prior to the experiment, as determined in the pilot experiment, and they were not fed during the last 7 days of the acclimation period. After this time, a glass divider was placed in each aquarium completely isolating the piscivore $H$. unitaeniatus at the side with macrophytes. Moenkhausia forestii individuals were then placed at the predator-free side of each aquarium and acclimated to these conditions for $24 \mathrm{~h}$ without being fed, as also determined in the pilot. Then, Chironomidae larvae were placed at the side that had submerged macrophytes and the piscivore. In the experimental units without the predator, the same number of $M$. forestii individuals and Chironomidae larva were added. A glass divider was also used to separate the fish from the macrophytes, and Chironomidae larvae were added at the macrophyte side of the aquarium. This glass divider was used to assure that predators were never in contact with their prey during the acclimation period. After half an hour, the divider was removed from both predator-absent and predator-present experimental units, allowing predators and preys to interact, and the experiment started.

The experiment ran for two hours, time in which three Hoplerythrinus unitaeniatus had consumed all six Moenkhausia forestii in the aquaria. Fish activity was constantly monitored. Videos were taken from some of the aquaria to record fish behavior. Next, H. unitaeniatus individuals were removed from each aquarium and returned to the tanks, posteriorly being deposited in the ichthyological collection of the Núcleo de Pesquisas em Limnologia, Ictiologia e Aquicultura (Nupelia). Remaining $M$. forestii individuals from each aquarium were counted, removed and preserved in $10 \%$ formalin for posterior stomach analysis. Stomachs were removed, opened and analyzed under the stereomicroscope, and the number of Chironomidae larva found in each stomach was counted, enabling the determination of individual consumption rates for survival M. forestii. In order to recover and quantify remaining Chironomidae larva, all macrophyte segments from each aquarium were manually and thoroughly scanned visually and water from each aquarium was filtered in a $0.5 \mathrm{~mm}$ mesh net.
Behavioral observations. Fish behavior was recorded by filming at least one experimental unit in each treatment. Videos started before the glass divider was removed from the aquaria. Fifteen minutes of each video were watched, after discarding the first minute. Hoplerythrinus unitaeniatus and Moenkhausia forestii individuals were watched and, every minute, fish position, activity (foraging, swimming or resting), and $M$. forestii shoal formation (aggregation of two or more individuals) were recorded. We also classified the general predatory behavior of $H$. unitaeniatus for the entire video in sit-and-wait or active foraging strategy, and recorded the number and location (open area or macrophyte bank) of attacks on prey (attempting to capture prey) by this piscivore. Chironomidae larvae behavior was not recorded.

Data analysis. To determine the effect of habitat complexity on prey consumption in different trophic levels, we analyzed predator-specific prey consumption, separately for Moenkhausia forestii and Hoplerythrinus unitaeniatus. A Two-Way ANOVA was conducted to assess the effect of habitat complexity and presence of the piscivore on $M$. forestii prey consumption (the percentage of consumed Chironomidae), with type III sum of squares to correct for the unbalanced design. A One-Way ANOVA was performed to determine the effect of factor habitat complexity on $H$. unitaeniatus prey consumption (the percentage of consumed $M$. forestii), since this factor alone influenced experimentally the interaction between the piscivore and its prey.

A Pearson correlation was performed between the percentage of consumed Chironomidae larvae and the percentage of consumed Moenkhausia forestii, in the presence of the piscivore, to evaluate the effect of piscivory intensity on resource consumption by its prey. Data were normally distributed (Shapiro-Wilk; $p>0.07$ ) and variances were homogeneous (Levene's test; $p>0.53$ ). We could not make any statistical inference with the behavioral data because there were no video replicates for all treatments, so we considered these as descriptive data. Statistical procedures and figures were made using the software Statistica 7.1 (StaTsOFt INC., 2007).

\section{RESULTS}

We found no significant effect of the interaction between habitat complexity and presence of piscivore on the percentages of Chironomidae larvae consumed by Moenkhausia forestii $\left(\mathrm{F}_{(2,18)}=0.55 ; \mathrm{p}=0.59\right)$. Mean percentages and standard error of consumed Chironomidae larvae in the presence of the piscivore were 79.0 $06.5,78.0 \pm$ 9.8 and $66.0 \pm 8.2$, and in the absence of the piscivore they were $65.0 \pm 8.6,83.3 \pm 12.0$, and $63.3 \pm 7.2$, respectively in low, intermediate and high habitat complexity (Fig. 2). Stomach content analysis of $M$. forestii showed that $90 \%$ (28 out of 31) of the surviving M. forestii did not consume any Chironomidae larvae in the presence of the piscivore. On the other hand, $52 \%$ ( 28 out of 54 ) of individuals did not consume any larvae in the absence of the piscivore.

There was also no effect of habitat complexity on prey consumption by Hoplerythrinus unitaeniatus $\left(\mathrm{F}_{(2,12)}=\right.$ 
$0.56 ; \mathrm{p}=0.58$ ). Mean percentages of consumed Moenkhausia forestii in the presence of the piscivore were $73.3 \pm 15.4$, $66.7 \pm 11.7$ and $53.3 \pm 13.3$ in low, intermediate and high habitat complexity respectively (Fig. 3 ).

The Pearson correlation between the percentage of Moenkhausia forestii consumed by Hoplerythrinus unitaeniatus and the percentage of Chironomidae larvae consumed by $M$. forestii, in the presence of the piscivore, was significant and positive $(\mathrm{r}=0.54 ; \mathrm{p}=0.04)$ (Fig. 4), independently of habitat complexity. This result shows that, in the presence of the piscivore, prey consumption by $M$. forestii increases as the intensity of the piscivory increases.

The behavioral data indicated a decrease in shoal formation and an increase in macrophyte bank use by Moenkhausia forestii individuals in the presence of the Hoplerythrinus unitaeniatus, especially when this piscivore was more active. In low habitat complexity, the recorded piscivore showed more predominantly an active foraging strategy and most of the attacks on prey occurred in the open area. In intermediate habitat complexity, the recorded individual showed a combination of sit-and-wait and active foraging strategies, and had the same number of attacks on prey in the open area and in the macrophyte bank. In high habitat complexity, the piscivore showed a clear sit-and-wait behavior, remaining most of the time inside macrophytes, and had the fewer number of attacks on prey.

\section{DISCUSSION}

In this study, we found no significant effect of habitat complexity on prey consumption by predators. These results do not support the hypothesis that greater habitat complexities decrease predator foraging success. Despite well-documented effects of habitat complexity on diminishing predation interactions (see KovALENKo et al., 2012), some studies also found little effect of habitat complexity on the outcome of the interaction between predators and preys (e.g. SAVINO \& SteIn, 1989; WARFE \& BARMUTA, 2004; HorinOUCHI et al., 2009; EINFALT et al., 2012; Hovel et al., 2016). Considering that fish present flexibility in their foraging behavior, (Magurran, 1993; Persson et al., 1997), prey capture success by predators may also depend on behavioral modifications of both predator and prey (SAVINO \& STEIN, 1989; Heck \& Crowder, 1991; JAMES \& HeCK JR., 1994; Hovel et al., 2016).

In the case of piscivores, such as $H$. unitaeniatus, changes in foraging tactics can lead to similar predation success in structured and non-structured environments (SAvino \& Stein, 1989; Ahrenstorff et al., 2009). For example, EINFALT et al. (2012) compared the behavior of a piscivore in laboratory experiments and found that it switched from an active foraging strategy, in open waters, to a sit-andwait strategy, in vegetated areas, which led to similar prey capture rates in the presence and in the absence of vegetation. Despite not being able to assess statistical differences in the behavior of Hoplerythrinus unitaeniatus, we also observed a change in foraging strategy by this piscivore in low and

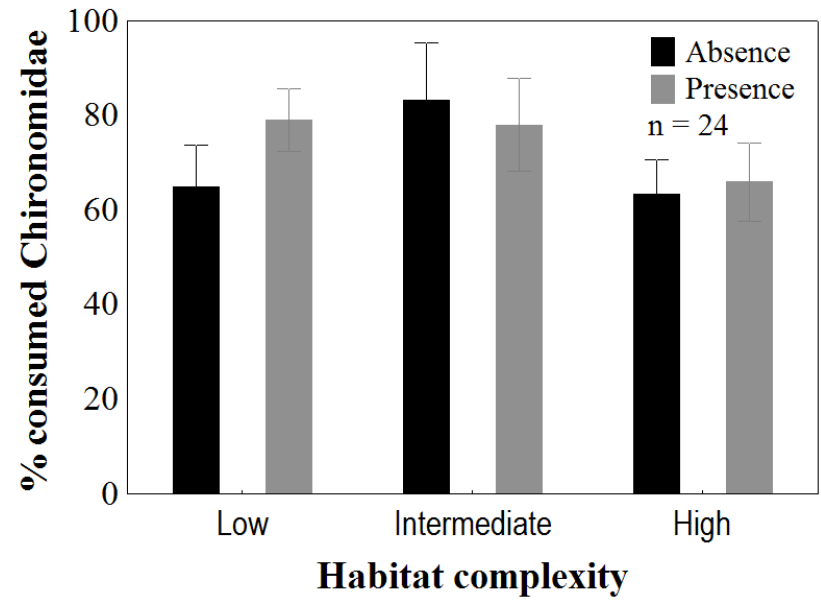

Fig. 2. Percentage of Chironomidae larvae consumed by Moenkhausia forestii Benine, Mariguela \& C. de Oliveira, 2009 in low, intermediate and high habitat complexities in the presence and in the absence of the piscivore Hoplerythrinus unitaeniatus (Spix \& Agassiz 1829).

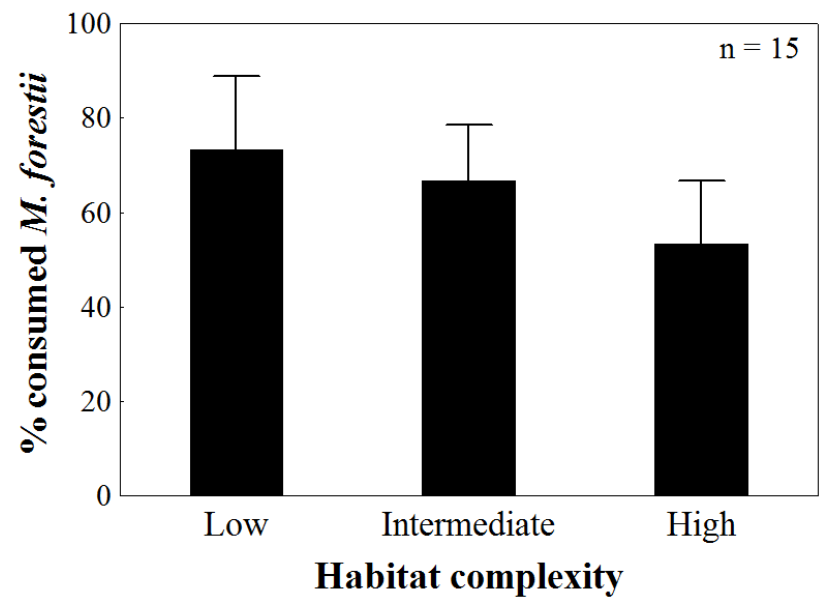

Fig. 3. Percentage of Moenkhausia forestii Benine, Mariguela \& C. de Oliveira, 2009 individuals consumed by Hoplerythrinus unitaeniatus (Spix \& Agassiz 1829) in low, intermediate and high habitat complexities.

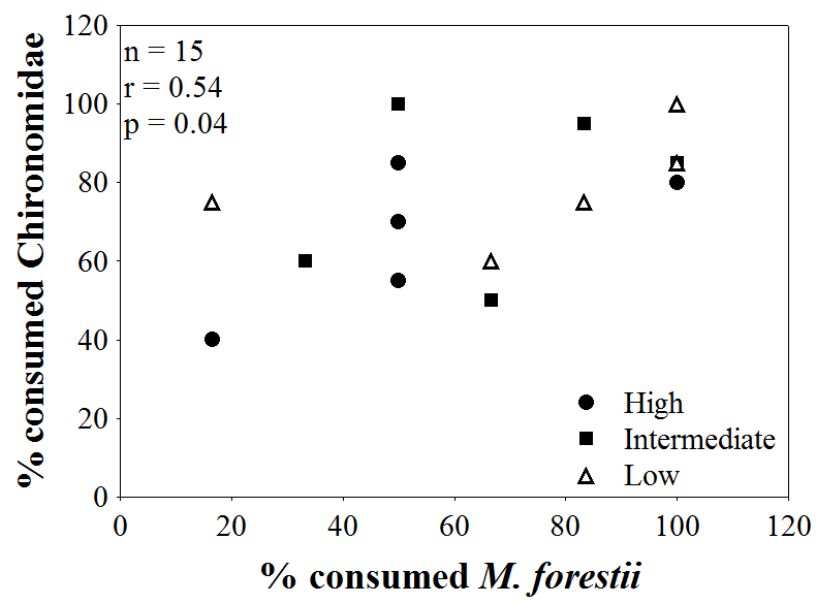

Fig. 4. Correlation between the percentages of Chironomidae larvae consumed by Moenkhausia forestii Benine, Mariguela \& C. de Oliveira, 2009 and the percentage of individuals of $M$. forestii consumed by Hoplerythrinus unitaeniatus (Spix \& Agassiz 1829) in the all levels of habitat complexity. 
high macrophyte densities. Such behavioral flexibility in $H$. unitaeniatus has already been observed in other experimental studies as well (R. B. BELINI, unpubl. data). Considering the findings in EINFALT et al. (2012) and the observed changes in predation behavior by the piscivore, we can consider that the similarity in prey consumption by $H$. unitaeniatus in different levels of habitat complexity, in our experiment, may have resulted from behavior differences in foraging strategy of fish individuals (Fig. 5). Moreover, it appears that the period of starvation of the piscivore was too long, what increased their hunger and foraging activity, masking the effect of habitat complexity on prey consumption rates. On the other hand, negative modelling results of refuge presence in a Lotka-Volterra's predator-prey model (PIANA et al., 2006) suggest that fish predators may have adaptations that assure their foraging optimization (i.e. cost reduction) in environments with and without refuge for prey (AHRENSTORFF et al., 2009).

The behavioral observations also showed that Moenkhausia forestii individuals used submerged macrophyte areas as refuge, thus decreasing, in some degree, the predation pressure exerted by Hoplerythrinus unitaeniatus, since the fractal structure of more complex habitats often works as physical barriers against predation (SAVINO \& STEIN, 1982; MANATUNGE et al., 2000). This may have been the case especially in high habitat complexity, since this treatment showed less consumption of $M$. forestii by $H$. unitaeniatus.

On the other hand, submerged macrophytes may have not worked as ideal refuge for the Chironomidae larvae in this experiment, especially for individuals collected in the sediment, which as the case in this study. Prey pigmentation influences the foraging success of visual predators (ZARET \&

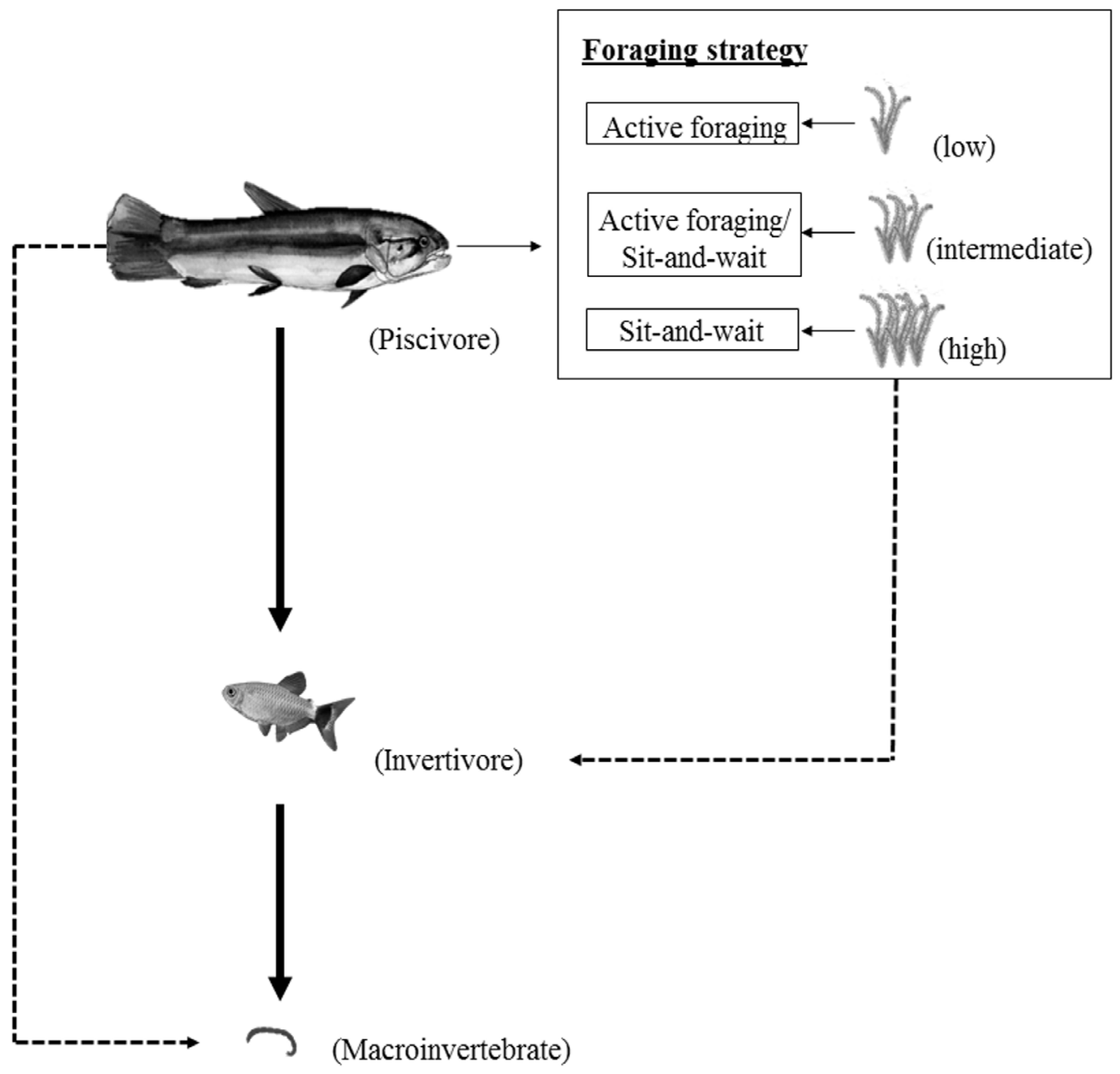

Fig. 5. Conceptual scheme describing prey consumption by Hoplerythrinus unitaeniatus (Spix \& Agassiz 1829) and Moenkhausi forestii Benine, Mariguela \& C. de Oliveira, 2009 reported in this experimental study. Bold solid arrows represent trophic interactions and thin solid arrows represent direct effects. Dashed arrow represents indirect effects. Habitat complexity, represented by macrophytes density, affects prey capture strategy of $H$. unitaeniatus and indirectly affects invertivore foraging. 
KERFOOT, 1975; JÖNSSON et al., 2011), thus the contrast between larvae body and the macrophyte background may facilitate its visual detection by the invertivorous Moenkhausia forestii. Larvae low mobility may also have made them easy targets for $M$. forestii once visualized, independently of habitat complexity or predator presence.

Lima \& Dill (1990) highlight possible outcomes of a predator-prey encounter situation but, in short, higher encounter rates usually result in higher predation rates. Prey movement can influence this encounter rate between predator and prey (ABrams, 1984; SKeLLY, 1994), and predator and prey movement is usually related to foraging or refuging activities. Thus, the more active Moenkhausia forestii individuals probably became easier prey for Hoplerythrinus unitaeniatus, irrespective of habitat complexity, resulting in the positive correlation between consumption rates. The stomach analyzes corroborate this result, since most of the remaining $M$. forestii had not consumed any Chironomidae larvae. Three level trophic interactions are a complex topic to be researched in experimental trials, especially when behavioral factors come into play. In this study, we found no effect of habitat complexity in prey consumption in a three-level trophic chain, and we attributed that result to possible behavioral patterns showed by the piscivore and the invertivore, seen in our recording. The behavior of predators and prey is an important variable to be studied to elucidate the mechanisms involved in the influence of habitat complexity on predator-prey interactions (e.g. WARFE \& Barmuta, 2004; Einfalt et al., 2012; Alexander et al., 2015; Hovel et al., 2016). Yet, the use of experiments is an important tool to unravel these mechanisms. Future studies may investigate the exact contribution of behavioral differences to the foraging success of predators depending on habitat complexity, the trade-offs between energy acquisition and risk of predation and the interactions of these factors in different trophic levels.

Acknowledgments. We thank Sebastião Rodrigues and José Trentin for technical and logistical support in field collections and aquarium maintenance. We also thank Igor de Paiva Affonso e Bruno Renaly Souza Figueiredo for helpful suggestions and guidance during the execution of the project and to the initial manuscript. Support for this research was provided by the Coordenação de Aperfeiçoamento de Pessoal de Nivel Superior (CAPES) and Conselho Nacional de Desenvolvimento Cientifico e Tecnológico (CNPq) through general funds. Fish individuals used in the experiment were deposited at the ichthyological collection of the Núcleo de Pesquisas em Limnologia, Ictiologia e Aquicultura (Nupélia/UEM). All applicable international, national, and/or institutional guidelines for the care and use of animals were followed. The authors declare that they have no conflict of interest.

\section{REFERENCES}

Abrams, P. A. 1984. Foraging time optimization and interactions in food webs. American Naturalist 124(80):112-132.

Agostinho A. A.; Gomes, L. C. \& Julio JR., H. F. 2003. Relações entre macrófitas aquáticas e fauna de peixes. In: Thomaz, S. N. \& BinI, L. M. eds. Ecologia e manejo de macrófitas aquáticas. Maringá, EDUEM, p. 261-279.

AhrenstorfF, T. D.; SAss, G. G. \& Helmus, M. R. 2009. The influence of littoral zone coarse woody habitat on home range size, spatial distribution, and feeding ecology of largemouth bass (Micropterus salmoides). Hydrobiologia 623:223-233.

Ajemian, M. J.; Sohel, S. \& Mattila, J. 2015. Effects of turbidity and habitat complexity on antipredator behavior of three-spined sticklebacks (Gasterosteus aculeatus). Environmental Biology of Fishes 98:45-55.

Alexander, M. E.; Kaiser, H.; Weyl, O. L. F. \& Dick, J. T. A. 2015. Habitat simplification increases the impact of a freshwater invasive fish. Environmental Biology of Fishes 98:477-486.

Almeida, V. L. L.; Hahn, N. S. \& Vazzoler, A. E. A. DE M. 1997. Feeding patterns in five predatory fishes of the high Parana River floodplain (PR, Brazil). Ecology of Freshwater Fish 6:123-133.

August, P. V. 1983. The role of habitat complexity and heterogeneity in structuring tropical mammal communities. Ecology 64:1495-1507.

BECK, M. W. 2000. Separating the elements of habitat structure: independent effects of habitat complexity and structural components on rocky intertidal gastropods. Journal of Experimental Marine Biology and Ecology 249:29-49.

BeuKers, J. S. \& Jones, G. P. 1997. Habitat complexity modifies the impact of piscivores on a coral reef fish population. Oecologia 114:50-59.

Britski, H. A.; Silimon, K. Z. S. \& Lopes, B. S. 1999. Peixes do Pantanal: manual de identificação. Brasília, Embrapa-SPI. 227p.

BuRKs, R. L.; JePPESEN, E. \& LODGE, D. M. 2001. Littoral zone structures as Daphnia refugia against fish predators. Limnology and Oceanography 46:230-237.

Canfield, D.E.; Shireman, J. V.; Colle, D. E.; Haller, W. T.; Watkins II, C. E. \& MaCEINA, M. J. 1984. Prediction of chlorophyll a concentrations in Florida lakes: importance of aquatic macrophytes. Canadian Journal of Fisheries and Aquatic Sciences 41:497-501.

Carniatto, N.; Fugi, R.; Thomaz, S. M. \& Cunha, E. R. 2014. The invasive submerged macrophyte Hydrilla verticillata as a foraging habitat for small-sized fish. Natureza e Conservação 12:30-35.

CASATti, L. 2003. Alimentação dos peixes em um riacho do Parque Estadual Morro do Diabo, bacia do Alto Rio Paraná, sudeste do Brasil. Biota Neotropica 2:1-14.

Crowder, L. B. \& COOPER, W. E. 1982. Habitat structural complexity and the interaction between bluegill and their prey. Ecology 63:1802-1813.

Cunha, E. R.; Thomaz, S. M.; Evangelista, H. B. A.; Carniato, J.; Souza, C. F. \& Fugi, R. 2011. Small-sized fish assemblages do not differ between a native and a recently established non-indigenous macrophyte in a neotropical ecosystem. Natureza e Conservação 9:61-66.

DieHL, S. 1988. Foraging efficiency of three freshwater fishes: effects of structural complexity and light. Oikos 53:207-214.

Einfalt, L. M.; Grace, E. J. \& WahL, D. H. 2012. Effects of simulated light intensity, habitat complexity and forage type on predator-prey interactions in walleye Sander vitreus. Ecology of Freshwater Fish 21:560-569.

Figueiredo, B. R. S.; Mormul, R. P. \& Benedito, E. 2013. Non-additive effects of macrophyte cover and turbidity on predator-prey interactions involving an invertivorous fish and different prey types. Hydrobiologia 716:21-28.

Figueiredo, B. R. S.; Mormul, R. P. \& Benedito, E. 2015a. Structural complexity and turbidity do not interact to influence predation rate and prey selectivity by a small visually feeding fish. Marine and Freshwater Research 66:170-176.

Figueiredo, B. R. S.; Mormul, R. P.; Chapman, B. B.; Lolis, L. A.; Fiori, L. F. \& BenEDito, E. 2016. Turbidity amplifies the non-lethal effects of predation and affects the foraging success of characid fish shoals. Freshwater Biology 61:293-300.

Figueiredo, B. R. S.; Mormul, R. P. \& Thomaz, S. M. 2015b. Swimming and hiding regardless of the habitat: prey fish do not choose between a native and a non-native macrophyte species as a refuge. Hydrobiologia 746:285-290.

Gomes, L. C.; Bulla, C. K.; Agostinho, A. A.; Vasconcelos, L. P. \& MirandA, L. E. 2012. Fish assemblage dynamics in a Neotropical floodplain relative to aquatic macrophytes and the homogenizing effect of a flood pulse. Hydrobiologia 685:97-107.

Gotceitas, V. \& Colgan, P. 1989. Predator foraging success and habitat complexity: quantitative test of the threshold hypothesis. Oecologia 80:158-166. 
GrabowsKi, J. H. 2004. Habitat complexity disrupts predator-prey interactions but not the trophic cascade on oyster reefs. Ecology 85(4):995-1004.

GrabowsKi, J. H. \& Kimbro, D. L. 2005. Predator-avoidance behavior extends trophic cascades to refuge habitats. Ecology 86(5):1312-1319.

Gratwicke, B. \& Speight, M. R. 2005. The relationship between fish species richness, abundance and habitat complexity in a range of shallow tropical marine habitats. Journal of Fish Biology 66:650-667.

Hahn, N. S.; Fugi, R. \& Andrian, I. F. 2004. Trophic ecology of the fish assemblages. In: Thomaz, S. M.; Agostinho, A. A. \& Hahn, N. S. eds. The Upper Parana River and its Floodplain: physical aspects, ecology and conservation. Leiden, Backhuys Publishers, p. 247-270.

HeCK, K. L. \& Crowder, L. B. 1991. Habitat structure and predator-prey interactions in vegetated aquatic systems. In: BeLL, S. S.; McCor, E. D. \& MushinsKy, H. R. eds. Habitat structure: the physical arrangements of objects in space. Netherlands, Chapman and Hall, p. 281-299.

Heck, K. L. \& Thoman, T. A. 1981. Experiments on predator-prey interactions in vegetated aquatic habitats. Journal of Experimental Marine Biology and Ecology 53:125-134.

Hixon, M. A. \& Menge, B. A. 1991. Species Diversity: prey refuges modify the interactive effects of predation and competition. Theoretical Population Biology 39:178-200.

HorinOuChi, M.; Mizuno, N.; Jo, Y.; FuJITA, M.; SANo, M. \& SuzuKi, Y. 2009. Seagrass habitat complexity does not always decrease foraging efficiencies of piscivorous fishes. Marine Ecology Progress Series 377:43-49.

Hovel, K. A.; Warneke, A. M.; Virtue-Hilborn, S. P. \& Sanchez, A. E. 2016. Mesopredator foraging success in eelgrass (Zostera marina L.): Relative effects of epiphytes, shoot density, and prey abundance. Journal of Experimental Marine Biology and Ecology 474:142-147.

Huang, J.; Zheng, X.; Wu, Z.; Liu, H. \& Deng, F. 2016. Can increased structural complexity decrease the predation of an alien crayfish on a native fish? Hydrobiologia 781:1-7.

JAMES, P. L. \& HeCK JR., K. L. 1994. The effects of habitat complexity and light intensity on ambush predation within a simulated seagrass habitat. Journal of Experimental Marine Biology and Ecology 176:187-200.

JÖNSOON, M.; Hylander, S.; RANÅKeR, L.; NiLSSON, P. A. \& BRÖNMARK, C. 2011. Foraging success of juvenile pike Esox lucius depends on visual conditions and prey pigmentation. Journal of Fish Biology 79:290-297.

Kovalenko, K. E.; Thomaz, S. M. \& Warfe, D. M. 2012. Habitat complexity: approaches and future directions. Hydrobiologia 685:1-17.

Lima, S. L. 1998. Nonlethal effects in the ecology of predator-prey interactions. BioScience 48:25-34

Lima, S. L. \& Dill, L. M. 1990. Behavioral decisions made under the risk of predation: a review and prospectus. Canadian Journal of Zoology 68:619-640.

Luz-Agostinho, K. D. G.; Agostinho, A. A.; Gomes, L. C. \& Júlio JR., H. F. 2008. Influence of flood pulses on diet composition and trophic relationships among piscivorous fish in the upper Parana River floodplain. Hydrobiologia 607:187-198.

MacArthur, R. H. \& MacArthur, J. W. 1961. On bird species diversity. Ecology 42(3):594-598.

MagurRan, A. E. 1993. Individual fish differences and alternative behaviours. In: PITCHER, T. J. ed. Behaviour of teleost fishes. London, Chapman and Hall, p. 441-477.

Manatunge, J.; Asaeda, T. \& Priyadarshana, T. 2000. The influence of structural complexity on fish-zooplankton interactions: a study using artificial submerged macrophytes. Environmental Biology of Fishes 58:425-438.

Mattila, J. 1992. The effect of habitat complexity on predation efficiency of perch Perca fluviatilis L. and ruffe Gymnocephalus cernuus (L.). Journal of Experimental Marine Biology and Ecology 157:55-67.

McCoy, E. D. \& BeLL, S. S. 1991. Habitat structure: the evolution and diversification of a complex tropic. In: BeLL, S. S.; MCCoy, E. D. \& MUSHINSKU, H. R. eds. Habitat structure: the physical arrangements of objects in space. London, New York, Chapman and Hall, p.3-27.

Mormul, R. P.; Vieira, L. A.; Pressinatte, S.; Monkolski, A. \& Dos SANTos, A. M. 2006. Sucessão de invertebrados durante o processo de decomposição de duas plantas aquáticas (Eichhornia azurea e Polygonum ferrugineum). Acta Scientiarum, Biological Sciences 28:109-115.

Padial, A. A.; Thomaz, S. M. \& Agostinho, A. A. 2009. Effects of structural heterogeneity provided by the floating macrophyte Eichhornia azurea on the predation efficiency and habitat use of the small Neotropical fish Moenkhausia sanctaefilomenae. Hydrobiologia 624:161-170.

Persson, L.; Diehl, S.; Eklov, P. \& Christensen, B. 1997. Flexibility in fish behavior: consequences at the population and community levels. In: Godin, J. J. ed. Behavioural ecology of teleost fishes. Oxford, Oxford University Press, p. 316-343.

Persson, L. \& EKLOV, P. 1995. Prey refuges affecting interactions between piscivorous perch and juvenile perch and roach. Ecology 76(1):70-81.

Piana, P. A.; Gomes, L. C. \& Agostinho, A. A. 2006. Comparison of predator-prey interaction models for fish assemblages from the neotropical region. Ecological Modelling 192:259-270.

Piko, A. A. \& SzedlmaYer, S. T. 2007. Effects of habitat complexity and predator exclusion on the abundance of juvenile red snapper. Journal of Fish Biology 70:758-769.

Savino, J. F. \& Stein, R. A. 1982. Predator-prey interaction between largemouth bass and bluegills as influenced by simulated, submersed vegetation. Transactions of the American Fisheries Society 111(3):255-266.

Savino, J. F. \& Stein, R. A. 1989. Behavioral interactions between fish predators and their prey: effects of plant density. Animal Behaviour 37:311-321.

SKelLY, D. K. 1994. Activity level and the susceptibility of anuran larvae to predation. Animal Behaviour 47:465-468.

Sousa, W. T. Z.; Thomaz, S. M. \& Murphy, K. J. 2010. Response of native Egeria najas Planch. and invasive Hydrilla verticillata (L.f.) Royle to altered hydroecological regime in a subtropical river. Aquatic Botany 92:40-41.

StATSOFt, InC. 2007. Statistica. Data analysis software system. Accessible at www.statsoft.com

Takeda, A. M.; Souza-Franco, G. M.; Mello, S. M. \& Monkolski, A. 2003. Invertebrados associados a macrófitas aquáticas da planície de inundação do alto rio Paraná (Brasil). In: ThOMAz, S. N. \& BINI, L. M. eds. Ecologia e manejo de macrófitas aquáticas. Maringá, EDUEM, p. 243-260.

TANiguchi, H.; NAKANO, S. \& ToKeshi, M. 2003. Influences of habitat complexity on the diversity and abundance of epiphytic invertebrates on plants. Freshwater Biology 48:718-728.

Thomaz, S. M. \& CunHa, E. R. D. 2010. The role of macrophytes in habitat structuring in aquatic ecosystems: methods of measurement, causes and consequences on animal assemblages composition and biodiversity. Acta Limnologica Brasiliensia 22(2):218-236.

Thomaz, S. M.; Dibble, E. D.; Evangelista, L. R.; Higuti, J. \& Bini, L. M. 2008. Influence of aquatic macrophyte habitat complexity on invertebrate abundance and richness in tropical lagoons. Freshwater Biology 53:358-367.

Tófoli, R. M.; Hahn, N. S.; Alves, G. H. Z. \& NovaKowski, G. C. 2010. Uso do alimento por duas espécies simpátricas de Moenkhausia (Characiformes, Characidae) em um riacho da Região Centro-Oeste do Brasil. Iheringia, Série Zoologia 100(3):201-206.

TOKESHI, M. \& ARAKAKI, S. 2012. Habitat complexity in aquatic systems: fractals and beyond. Hydrobiologia 685:27-47.

TuRner, A. M. 1997. Contrasting short-term and long-term effects of predation risk on consumer habitat use and resources. Behavioral Ecology 8(2): 120-125.

WARFE, D. M. \& BARMUTA, L. A. 2004. Habitat structural complexity mediates the foraging success of multiple predator species. Oecologia 141:171-178.

Warfe, D. M. \& Barmuta, L. A. 2006. Habitat structural complexity mediates food web dynamics in a freshwater macrophyte community. Oecologia 150:141-154.

Zaret, T. M. \& Kerfoot, W. C. 1975. Fish predation on Bosmina longirostris: body-size selection versus visibility selection. Ecology 56(1):232-237. 